\title{
Micropropagation of Morus cathayana through in vitro culture from local Bogor, West Java, Indonesia
}

\author{
YASINTA RATNA ESTI WULANDARI", MENWANGI ADRIANASHINTA HARJOSUDIRJO \\ Department of Biology, Faculty of Biotechnology, Atma Jaya Catholic University of Indonesia, Jalan Jenderal Sudirman No. 51, South Jakarta12930, \\ Jakarta, Indonesia. Tel.: +62-21-5703306, Fax.: +62-21-5708811, `email: yasinta.ratna@atmajaya.ac.id
}

Manuscript received: 25 August 2018. Revision accepted: 8 January 2019.

\begin{abstract}
Wulandari YRE, Harjosudirjo MA. 2019. Micropropagation of Morus cathayana through in vitro culture from local Bogor, West Java, Indonesia. Nusantara Bioscience 11: 18-22. Mulberry (Morus spp.) is a dicotyledonous plant known for its medicinal benefits as well as silkworm breeding (Bombyx mori L.) to produce silk. Morus cathayana mainly cultivated due to its high content of 1deoxynojirimycin, widely utilized as an anti-diabetic agent. However, common practice in planting and maintenance of mulberry generate less profit, contributed to its long juvenile period and high heterozygosity level. Hence the development and cultivation through plant tissue culture techniques are necessary. The purpose of this research was to obtain the best combination of thidiazuron as a plant growth regulator. $M$. cathayana branches with nodal segments were used as explants. Research stages were explants initiation into Murashige and Skoog media, shoot induction in MS media as control and MS+BAP $1 \mathrm{mg} / \mathrm{L}+\mathrm{NAA} 0.25 \mathrm{mg} / \mathrm{L}+\mathrm{TDZ} 0.1,0.5,1 \mathrm{mg} / \mathrm{L}$ as treatment media, and statistical data analysis. Greater increase in shoot growth was observed in MS+BAP $1 \mathrm{mg} / \mathrm{L}+\mathrm{NAA} 0.25$ $\mathrm{mg} / \mathrm{L}+\mathrm{TDZ} 0.5 \mathrm{mg} / \mathrm{L}$ media, while the formation of shoots and calluses on the explants grown in control and treatment media showed no significant growth.
\end{abstract}

Keywords: 1-deoxynojirimycin, BAP, NAA, nodal explant, thidiazuron

\section{INTRODUCTION}

Mulberry (Morus spp.) is a dicotyledonous plant of Moraceae family, widely used for medical purposes and silkworm breeding (Bombyx mori L.) (Lalitha et al. 2013). A mulberry species commonly cultivated is Morus cathayana, since it has high content of 1-deoxynojirimycin (DNJ) in their leaves (Wulandari 2016). This DNJ compound has the anti-hyperglycemic activity, generally applied as an antidiabetic agent (Asano et al. 2001). Furthermore, leaves also used as silkworm main diet, as it can boost the percentage value of cocoon and filament production (Wageansyah 2007).

Such benefits lead to public enthusiasm in consuming and growing $M$. cathayana, however, plant cultivation through seed propagation has some limitation since its long juvenile period and high cross-pollination frequency where the level of heterozygosity of this plant is high. According to Martinez et al. (2006), conventional methods for developing mulberry plants are no longer effective, this method takes time, labor, costs for land, and there is a possibility of lack of care and a large number of pests and insects also increases the risk of crop failure. Sometimes there are Xylella fastidiosa bacteria that cause Mulberry Leaf Scorch (MLS) disease. Therefore, plant tissue culture techniques are needed to produce plants with similar genotype characteristics within a short period of time (Vishwanathan et al. 2010; Nathaniel 2016).

Plant tissue culture is a technique which involved cells, tissues, and organs multiplication of plants propagated vegetatively using agar media with the addition of specific plant growth regulators (PGRs). By using this technique, plants with uniform superior characteristics will be obtained quite rapidly (Lestari 2011). Explants used in this research are stems which have nodal segments. This section selected due to its high meristematic activity which generates more rapid growth compared to other parts such as internodal segments. Moreover, the use of nodal segments will induce axillary bud formation to ensure the regeneration and genetic stability rate (Ongaro and Leyser 2007).

Key success of plant propagation through plant tissue culture is the PGRs that are added to the culture media. A type of PGR that is frequently used for woody plants such as mulberry is thidiazuron (TDZ), i.e. a phenyl-urea substance which has cytokinin activities. In order to accelerate bud formation and morphogenesis from explants, an appropriate combination of TDZ with other PGR is necessarily needed (Lalitha et al. 2013).

The aim of this research was to obtain the best combination of thidiazuron as a PGR supplemented into the media to propagate $M$. cathayana using nodal explants through in vitro technique.

\section{MATERIALS AND METHODS}

\section{Materials and Instruments}

Materials used in this research were 3 months-old mother's plant of $M$. cathayana that have been rejuvenated. Cutting of $M$. cathayana originated from University Farm of Bogor Agricultural University in Sukamantri, Bogor, West Java. Other materials required were $2.5 \%$ sodium 
hypochlorite, sterile distilled water, fungicide (Dithane M$452 \mathrm{~g} / \mathrm{L}$ ), Tween $^{\circledR}$ 20, 96\% and $70 \%$ alcohol, and Murashige and Skoog (MS) media using Phytagel ${ }^{\mathrm{TM}}$ from Sigma-Aldrich as solidifying agent with varied composition according to tissue culture stages, explant initiation and shoot induction. PGRs added to the agar media including thidiazuron (TDZ, Caisson Labs), Naphthalene Acetic Acid (NAA, Sigma-Aldrich), and 6Benzylaminopurine (BAP, Sigma-Aldrich).

The tools applied in this research were laminar air flow cabinet, autoclave, steam bath scales, scalpel with blade, tweezers, small and media size bottles, and petri dish. The laboratory apparatus in direct contact with the explants, should be sterilized through autoclaving at $121^{\circ} \mathrm{C}$ for 15 minutes at $1 \mathrm{~atm}$.

\section{Procedures}

Research method divided into two stages, micropropagation and data analysis. Micropropagation stage consisted of two main stages, stated as establishment and multiplication. The media used in establishment stage were MS media, whereas the media used in the multiplication stage consisted of two media types, i.e. MS media as control media and MS media supplemented with TDZ, NAA, and BAP as treatment media.

\section{Establishment}

This stage was explant adaptation stage from its original environment to a controlled laboratory environment, there is still possibility for explant to fail in adapting and being contaminated which could lead to explant's death. Branches with nodal segments were cut from mulberry plants (M. cathayana) and used as explants in this research, then the surface of these explants was sterilized, thoroughly, in running water for 30 minutes. Further sterilization steps were carried out in the laminar airflow cabinet. The water-sterilized explants placed into a jar containing 5\% detergent solution and shaken for 10 minutes, then transferred into a jar containing $2 \mathrm{~g} / \mathrm{L}$ Dithane M-45 fungicide and shaken for 15 minutes. Afterward, explants removed and rinsed in a jar containing sterile distilled water for 5 minutes, then the explants were transferred into a $70 \%$ alcohol-filled jar for 1 minute. Subsequently, the explants were transferred into a jar containing a mixture of $2.5 \%$ sodium hypochlorite and two drops of Tween $^{\circledR} 20$ which were then shaken for 10 minutes. Afterward, the explants were rinsed by transferring it three times into a jar containing sterile distilled water. The washed explants were then transferred to a petri dish containing a sterile filter paper, then the tips of the explants were trimmed off.
For survival rate, 50 explants were initiated into MS media and then incubated for approximately 30 days. During 30-days period of observation, explants were experiencing varieties of total contaminated explants, total survived explants, and plant survival rate with two repetitive. And then 12 explants from establishment stage proceed to the multiplication stage.

\section{Multiplication}

After incubated for 30 days, the 12 explants were transferred into multiplication media to induce the formation of shoots. The media used were divided into two groups, the control media (MS media) three explants, and the treatment media, namely MS, enriched with BAP 1 $\mathrm{mg} / \mathrm{L}$, NAA $0.25 \mathrm{mg} / \mathrm{L}$, and TDZ with three concentration variations $(0.1,0.5$, and $1 \mathrm{mg} / \mathrm{L})$ total of nine explants (triplicate for each treatment). Then, culture bottles were incubated in the plant culture room under tubular lamp for 30 days period. Explants growth observed periodically with parameters of increase in shoot length, shoot growth in the number of new shoots per explant, and the presence of callus.

\section{Data analysis}

Data obtained based on the observations were analyzed using statistical methods to find the best media composition and PGRs combination for micropropagation of $M$. cathayana. The analytical method to process the data was randomized design analysis using the $22^{\text {nd }}$ version of IBM Statistical Package for the Social Sciences (SPSS) program. The type of the test used based on the observation was Analysis of Variance (ANOVA) test with Bonferroni posthoc test.

\section{RESULTS AND DISCUSSION}

\section{Establishment}

The result of the establishment stage of Morus cathayana nodal explants presented in Table 1 and Figure 1. Table 1 reveals the percentage of survived explants or contaminated as a whole.

Table 1. Plant survival rate

\begin{tabular}{lllll}
\hline Batch & $\begin{array}{l}\text { Total } \\
\text { initiated } \\
\text { explants }\end{array}$ & $\begin{array}{l}\text { Total } \\
\text { contaminated } \\
\text { explants }\end{array}$ & $\begin{array}{l}\text { Total } \\
\text { survived } \\
\text { explants }\end{array}$ & $\begin{array}{l}\text { Plant } \\
\text { survival } \\
\text { rate (\%) }\end{array}$ \\
\hline 1 & 24 & 15 & 9 & 37.5 \\
2 & 26 & 7 & 19 & 73.1 \\
Total & 50 & 22 & 28 & 56 \\
\hline
\end{tabular}

Table 2. Bonferroni post-hoc test result of each test parameter

\begin{tabular}{llll}
\hline Media & Shoot growth $(\mathbf{c m})$ & No. of shoots & Callus \\
\hline MS & $0^{\mathrm{a}}$ & $0^{\mathrm{a}}$ & None \\
MS + BAP $1 \mathrm{mg} / \mathrm{L}+$ NAA $0.25 \mathrm{mg} / \mathrm{L}+\mathrm{TDZ} 0.1 \mathrm{mg} / \mathrm{L}$ & $0.167 \pm 0.03^{\mathrm{a}}$ & $1.000 \pm 0.58^{\mathrm{a}}$ & None \\
MS + BAP $1 \mathrm{mg} / \mathrm{L}+$ NAA $0.25 \mathrm{mg} / \mathrm{L}+\mathrm{TDZ} 0.5 \mathrm{mg} / \mathrm{L}$ & $0.367 \pm 0.12^{\mathrm{b}}$ & $1.333 \pm 0.33^{\mathrm{a}}$ & None \\
MS + BAP $1 \mathrm{mg} / \mathrm{L}+$ NAA $0.25 \mathrm{mg} / \mathrm{L}+\mathrm{TDZ} 1.0 \mathrm{mg} / \mathrm{L}$ & $0.100 \pm 0.06^{\mathrm{a}}$ & $0.333 \pm 0.33^{\mathrm{a}}$ & None \\
\hline
\end{tabular}

Note: Mean values $( \pm$ SE) followed by the same letters are not significantly different at the significance level of 0.05 . 


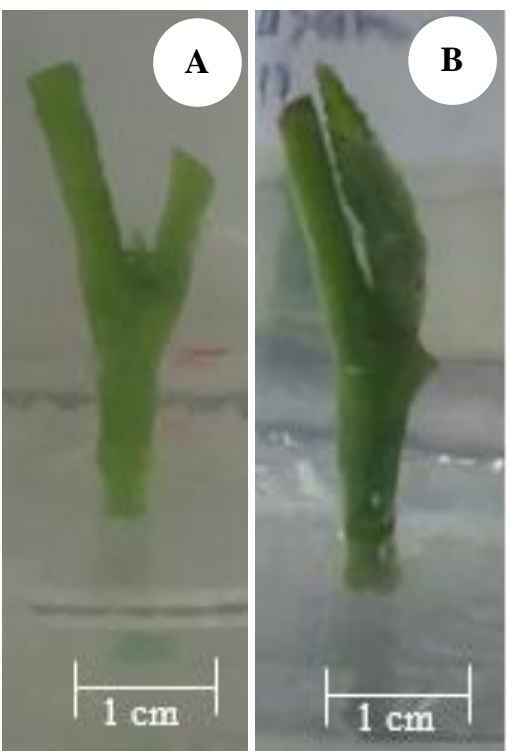

Figure 1. Nodal explants initiated in MS media before (A) and after (B) incubation period
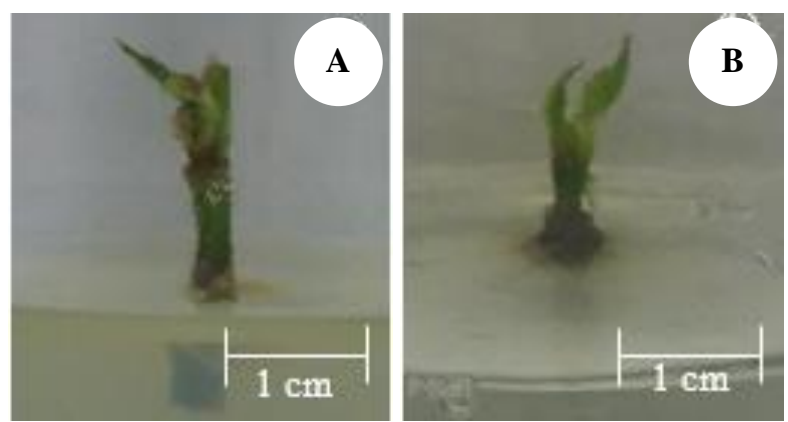

Figure 2. $M$. cathayana nodal explants initiated in control media (A) and $\mathrm{MS}+\mathrm{BAP} 1 \mathrm{mg} / \mathrm{L}$ + NAA $0.25 \mathrm{mg} / \mathrm{L}$ + TDZ $0.5 \mathrm{mg} / \mathrm{L}$ media (B) after 30 days incubation period

Out of 50 explants, 28 explants managed to survive and free from contamination as shown in Table 1. Thus, the percentage of plant survival obtained was equal to $56 \%$. All explants contaminated, either by bacteria or fungi. The contamination occurred due to the ability of microorganism to enter and survive in plant tissue, in which surface sterilization treatment found less effective in removing the intercellular microorganism contaminants (Reed and Tanprasert 1995).

\section{Multiplication}

The result of the multiplication stage of Morus cathayana nodal explants presented in Table 2 and Figure 2. The data obtained at this stage was processed using SPSS program. ANOVA test applied to examine the difference between explants planted on control media and treatment media. The Bonferroni post-hoc test resulted in a significant difference in the shoot growth test parameter with the addition of $0.5 \mathrm{mg} / \mathrm{L}$ thidiazuron in the treatment media.
Based on Bonferroni post-hoc test results at the multiplication stage (Table 2), a significant difference in shoot growth found in the treatment of MS + BAP $1 \mathrm{mg} / \mathrm{L}$ + NAA $0.25 \mathrm{mg} / \mathrm{L}+\mathrm{TDZ} 0.5 \mathrm{mg} / \mathrm{L}$ when compared to the explant planted in MS control media. Besides encouraging cell division, TDZ added to the multiplication media can also lead to cell lengthening and enlargement. This corresponds to the statement of Lu (1993), i.e. TDZ compound suspected of having auxin activity or being involved in the auxin metabolism process. This statement reinforced by the statement of Lestari (2011) who stated cell division through compound with auxin activity mainly occur in cambium tissue, so the addition of TDZ combined with NAA will trigger the growth of $M$. cathayana plantlet. In addition, Tewari et al. (1999) reported that the addition of TDZ at a concentration of $0.5 \mathrm{mg} / \mathrm{L}$ effectively improved the growth quality of Morus indica cv. S1. TDZ has the ability to induce the production of natural hormones contained in the plant tissue, so the addition of this hormone in the right concentration, neither too low or too high, will increase the efficiency of plant growth. TDZ concentration that is too low $(0.1 \mathrm{mg} / \mathrm{L})$ will not be sufficient to induce $M$. cathayana proliferation effectively, whereas TDZ concentration that is too high $(1 \mathrm{mg} / \mathrm{L})$ will inhibit $M$. cathayana growth due to accumulation and interference of hormones in plant tissues (Gondval et al. 2016).

Observation of shoot number showed the shoots which emerged from the planted explants, both on the control media and the treatment media, were observed periodically for approximately 30 days with an example of the result as shown in Figure 2. The result from data processing on this parameter indicated some differences in number of shoots formed between the explants planted on the control media and the treatment media with the best result obtained from the use of BAP $1 \mathrm{mg} / \mathrm{L}$ + NAA $0.25 \mathrm{mg} / \mathrm{L}$ + TDZ $0.5 \mathrm{mg} / \mathrm{L}$ media (Table 2). However, the difference was not significant towards control after further examination using Bonferroni post-hoc test. This result was in accordance with the statement from Tewari et al. (1999) that the addition of TDZ at a concentration of $0.5 \mathrm{mg} / \mathrm{L}$ would effectively increase the percentage of shoot formation in Morus indica cv. S1.

On the other hand, the insignificant difference could be resulted from shoot growth which was strongly influenced by the addition of TDZ and its concentration. TDZ added in low concentrations consider more effective in inducing shoot growth in explants (Sajeevan et al. 2011). The addition of TDZ into the multiplication media interfere the endogenous hormones due to the increased levels of cytokinins in plants. This increase of cytokinins level will inhibit the activity of cytokinin oxidase, resulting in cytokinins accumulation which then will inhibit the growth of shoots (Debnath 2005). In addition, the use of TDZ is also reported to cause changes in nitrate reductase, ATP, ribulose diphosphate carboxylase oxidase, and phosphate pentose enzymes so that it can be said that morphological mismatch between the initial hypothesis and the result 
obtained can be due to changes in plant enzyme kinetics (Guo et al. 2011).

Differences in plant species used between reference journal and research conducted also affected the results obtained. In the reference journal used for the initial determination of concentrations and combinations of growth regulators, the type of mulberry plant used was Morus alba var. V1, whereas in this research, the mulberry plant used was Morus cathayana (Sajeevan et al. 2011). Each plant has their own needs for the types and concentrations of hormones, depending on the physiology and plant tissue genotypes, so the results can also be different (Lestari 2011). Supriati et al. (2006) also stated that not all plants responded positively to shoot growth associated with the addition of TDZ, such as the addition of TDZ compound into the growth media of Belimbing Dewi which tend to increase the shoot length and the number of leaves, while the shoot number did not increase when compared to the control.

Other factor that may affect the results of this research was the type and combination of growth regulator substances which were added to the micropropagation media. The addition of TDZ can be done either with or without combination with other PGRs, but each treatment has its own advantages and disadvantages. Based on the research and literature studies that have been done, the addition of TDZ will provide more efficient plant growth results when combined with other PGRs, especially from the auxins group such as NAA. This was due to the nature of TDZ as a hormone with cytokinin activity, so the addition of this hormone needs to be balanced with auxin activity from other exogenous hormones to induce the growth of plants more effectively and efficiently. However, TDZ can also be added individually to the micropropagation media, especially if the hormone is added in a low concentration. Addition of TDZ alone in higher concentration $(2 \mathrm{mg} / \mathrm{L})$ will inhibit the growth of explant, both in terms of callus growth, buds, and leaves, so that the combination of this hormone with other hormones is necessarily needed (Gondval et al. 2016).

In the observation parameter of calluses presence, no calluses were formed throughout the research, either on the explants planted on control media or treatment media. The thidiazuron concentration is not large enough to induce callus formation in this experiment. In the research of Gill and Ozia-Akins (1999) and Elaleem et al. (2009), thidiazuron concentration between $1.0-5.0 \mathrm{mg} / \mathrm{L}$ able to induce callus formation. PGRs which play a major role in callus formation were derived from auxins group, such as NAA. The addition of PGRs from this group in high concentration, either with or without combination with other PGRs, will induce callus formation due to the modified activity of auxin-responsive specific gene involved in the process of plant development, resulting in continuous cell division (Lestari 2011; Kandasamy et al. 2001). The Absence of exogenous plant growth regulator is not able to induced callus growth, the same result was also obtained from the research by Balogun et al. (2007) and Elaleem et al. (2009).
In this research, PGRs added to the micropropagation media consisted of combined PGR group of cytokinins (TDZ, BAP) and auxins (NAA) with PGR concentration ratio of cytokinins group emerged more dominant when compared with PGR concentration of auxins group. This causes explants experienced tendency to form buds instead of callus. In addition, type of auxins PGRs applied could also influence the absence of callus on explants, since the type of auxins PGR stated could induce callus formation efficiently is 2,4-Dicholophenoxy Acetic Acid or 2,4-D, while in this research the auxins PGR used was NAA (Lestari 2011).

In conclusion, MS media supplemented with BAP 1 $\mathrm{mg} / \mathrm{L}+\mathrm{NAA} 0.25 \mathrm{mg} / \mathrm{L}+\mathrm{TDZ} 0.5 \mathrm{mg} / \mathrm{L}$ was the best media that can be used to micropropagate Morus cathayana using nodal explants. The use of this media will induce shoot extension effectively, while the formation of shoots on explants will also give different results between the planting done on the control media with the treatment media, although not significant. Moreover, no callus was formed throughout this research.

\section{ACKNOWLEDGEMENTS}

This research was financially supported by Faculty of Biotechnology, Atma Jaya Catholic University of Indonesia in 2016. We thank University Farm of Bogor Agricultural University in Sukamantri, Bogor, West Java in provide mulberry plants as samples in this research.

\section{REFERENCES}

Asano N, Yamashita T, Yasuda K, Ikeda K, Kizu H, Kameda Y, Kato A, Nash RJ, Lee HS, Ryu KS. 2001. Polyhydroxylated alkaloids isolated from mulberry trees (Morus alba L.) and silkworms (Bombyx mori L.). J Agric Food Chem 49 (9): 4208-4213.

Balogun MO, Akande SR, Ogunbodede BA. 2007. Effects on plant growth regulator on callus, shoots, and root formation in fluted pumpkin (Telfairia occidentalis). African J Biotechnol 6 (4): 355-358.

Debnath SC. 2005. A two-step procedure for adventitious shoot regeneration from in vitro-derived lingonberry leaves: shoot induction with TDZ and shoot elongation using zeatin. HortScience 40 (1): 189192.

Elaleem KGA, Modawi RS, Khakafalla MM. 2009. Effect of plant growth regulators on callus induction and plant regeneration in tuber segment culture of potato (Solanum tuberosum L.) cultivar Diamant. African J Biotechnol 9 (11): 2529-2534.

Gill, Ozia-Akins P. 1999. Thidiazuron-induced highly morphogenic callus and high-frequency regeneration of fertile peanut (Arachis hypogaea L.) plants. In Vitro Cell Dev Biol-Plant 35 (6): 445-450.

Gondval M, Chaturvedi P, Gaur AK. 2016. Thidiazuron-induced high frequency establishment of callus cultures and plantlet regeneration in Aconitum balfourii Stapf.: an endangered medicinal herb of NorthWest Himalayas. Indian J Biotechnol 15 (2): 251-255.

Guo B, Abbasi BH, Zeb A, Xu LL, Wei YH. 2011. Thidiazuron: a multidimensional plant growth regulator. African J Biotechnol 10 (45): 8984-9000.

Kandasamy MK, Gilliland LU, McKinney EC, Meagher RB. 2001. One plant actin isovariant, ACT7, is induced by auxin and required for normal callus formation. The Plant Cell 13 (7): 1541-1554.

Lalitha N, Kiho S, Banerjee R, Chattopadhyay S, Saha AK, Bindroo BB. 2013. High-frequency multiple shoot induction and in vitro regeneration of mulberry (Morus indica L. cv. S-1635). Intl J Adv Res 1 (1): 22-26. 
Lestari EG. 2011. Peranan zat pengatur tumbuh dalam perbanyakan tanaman melalui kultur jaringan. Jurnal AgroBiogen 7 (1): 63-68.

Lu CY. 1993. The use of thidiazuron in tissue culture. In vitro Cell Dev Biol Plant 29 (2): 92-96

Martinez RH, Pinkcard TR, Costa HS, Cooksey DA, Wong FP. 2006 Discovery and characterization of Xylella fastidiosa strains in Southern California causing mulberry leaf scorch. Amer Phytopathol Soc 90 (9): 1143-1149.

Nathaniel. 2016. Efisiensi media mikropropagasi Morus cathayana menggunakan tunas aksilar [Thesis]. Atma Jaya Catholic University of Indonesia, Jakarta. [Indonesian]

Ongaro V, Leyser O. 2007. Hormonal control of shoot branching. J Experimental Botany 59 (1): 67-74.

Reed BM, Tanprasert P. 1995. Detection and control of bacterial contaminants of plant tissue cultures. Plant Tiss Cult Biotechnol 1 (3): 137-142.

Sajeevan RS, Singh SJ, Nataraja KN, Shivanna MB. 2011. An efficient in vitro protocol for multiple shoot induction in mulberry, Morus alba $\mathrm{L}$ variety V1. Intl Res J Pharmaceut Sci 2 (8): 254-261.
Supriati Y, Mariska I, Mujiman. 2006. Multiplikasi tunas belimbing dewi (Averrhoa carambola) melalui kultur in vitro. Buletin Plasma Nutfah 12 (2): 50-55.

Tewari A, Bhatnagar S, Khurana P. 1999. In vitro response of commercially valuable cultivars of Morus species to thidiazuron and activated charcoal. Plant Biotechnol 16 (5): 413-417.

Vishwanathan AS, Pradhan A, Basavaraja R. 2010. Effect of nutrients on in vitro culture of Morus alba L. (white mulberry). Biores Bull 1 (1): 8-12.

Wageansyah RDR. 2007. Pengaruh pemberian berbagai jenis daun murbei (Morus spp.) terhadap pertumbuhan ulat sutera (Bombyx mori L.) dan kualitas kokon di Pusat Serikultur Sukamantri, Bogor [Thesis]. Bogor Agricultural University, Bogor. [Indonesian]

Wulandari YRE, Prasasty VD, Rio A, Geniola C. 2016. Determination of 1- deoxynojirimycin and phytochemical profile from mulberry leaves cultivated in indonesia. Inter $\mathbf{J}$ of Biotechnol and Bioengineer. 10(12): 1 . 